\title{
Rural Agricultural Change and Individual Out-migration
}

\begin{abstract}
We investigate the impact of household use of labor-saving farm technologies on first time out-migration after household agriculture and consumption survey in 1996. Building on the labor substitution framework, we hypothesize that household use of labor-saving technologies (e.g. tractors, farm implements, chemical fertilizers and pesticides) increase individual out-migration. To estimate the effects of the use of labor-saving farm technologies on out-migration, we use uniquely detailed panel data from the rapidly changing rural agrarian, migrant-sending setting of Nepal. The results of our multilevel discrete-time event history models suggest that net of other known factors associated with out-migration, household use of farm technology— particularly the use of tractorssignificantly increases out-migration.
\end{abstract}

Key words: agriculture, farm technologies, migration, rural, Nepal, South Asia

This is the author manuscript accepted for publication and has undergone full peer review but has not been through the copyediting, typesetting, pagination and proofreading process, which may lead to differences between this version and the Version record. Please cite this article as doi:10.1111/ ruso.12106. 


\section{Introduction}

Global population mobility is one of the most striking demographic changes witnessed more recently during the $20^{\text {th }}$ and $21^{\text {st }}$ century. More people are geographically mobile today than at any point in human history and are living abroad now more than ever. In 2013, 232 million people were international migrants (UN Press Release 2013), which increased from 214 million in 2010 (IOM 2010). With an estimated 232 million people moving internationally-mostly from poor, subsistence-based agricultural countries to rapidly industrializing, economically advanced countries-and approximately three quarters of a billion migrating from rural to peri-urban and urban areas within their countries, population mobility has gained significant attention in both scholarly and policy arenas.

Concurrently, rural agriculture is also experiencing a dramatic transition away from traditional farming systems towards increasingly mechanized, commercial farming systems (Majumdar, Dolui and Banerjee 2001; Mamdani 1972; Self 2008; Vosti, Witcover and Lipton 1994; World Bank Publications 2008). New technological innovations (e.g., mechanization, high-yielding crop varieties, improved animal breeds, chemical fertilizers and pesticides) and development of new markets have dramatically transformed subsistence-based farming into market-oriented commercial farming around the world (Majumdar et al. 2001; World Bank Publications 2008). Many rural subsistence farm households now increasingly rely on modern farm technologies (e.g., tractors, pumpsets, and improved farm implements), and chemicals (fertilizers and pesticides), resulting in a large surplus of farm labor. 
These societal changes have drawn great attention from scholars and have independently prompted a large number of studies both in agriculture science and population mobility (e.g., de Brauw, Taylor and Rozelle 1999; Jokisch 2002; Majumdar et al. 2001; Mamdani 1972; Vosti et al. 1994; World Bank Publications 2008). Scholars have developed various theoretical frameworks and offered a wide range of explanations for the dramatic changes in both migratory behavior and rural agriculture in their respective fields. Generally, these frameworks and explanations have been dominated by socioeconomic explanations, emphasizing employment opportunities and wage differences between place of origin and destination as drivers of migration and agricultural change (Sjaastad 1962; Todaro 1969; Todaro and Maruszko 1987; Stark and Bloom 1985; Stark and Levhari 1982; Stark and Taylor 1989; Stark and Taylor 1991; Taylor 1986; Taylor 1987). In addition, migration research on environmental determinants has focused on the influences of environmental conditions such as decline in agricultural productivity, land-use and land-cover change, deforestation, natural calamities and natural disasters on out-migration (Adamo 2009; Adamo and CrewsMeyer 2006; Gray 2009; Kalipeni 1996; Massey et al. 2010a; Myers 2002). Other commonly offered explanations include access to information and technology (farm technology for agriculture) with particular emphasis on rapid expansion of the availability of farm technology, transportation and communication networks, and the expansion of mass media (Piotrowski 2013; Piotrowski, Ghimire, and Rindfuss 2013; Piotrowski and Tong 2010).

However, despite the fact that an overwhelming majority of migrants are from poor, subsistence agricultural settings and there is ample theoretical reason to believe a 
link between out-migration and agriculture change, little empirical evidence explores this plausible relationship. Using comprehensive measures of communities, households, and individuals along with measures of agricultural change from an ongoing panel study, we examine the extent to which variation in agricultural systems-particularly the use of labor-saving farm technologies_-influences individual out-migration in a rural agrarian setting in Nepal.

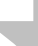
Linking agricultural change and labor out-migration in a post-frontier, poor, rural agricultural setting is important for both theoretical and practical reasons. Theoretically, as most modern farm technologies are designed to reduce human labor (Boserup 1965; Rauniyar and Goode 1996), a change in agricultural systems from labor-intensive subsistence agriculture to mechanized commercial agriculture is likely to generate a large surplus of farm labor (Agarwal 1983; Binswanger 1978; Massey et al. 1993; 1998).

Without available employment outside the farm, in most rural areas this surplus labor force will most likely migrate. However, investigations of out-migration from rural areas is scanty signifying a critical need for rigorous scientific investigation (de Brauw 2010; Ecer and Tompkins 2010; Jokisch 2002; Koc and Onan 2004; Seddon 2004; Taylor, Rozelle and de Brauw 2003).

From a policy perspective, in many rural agrarian societies - which are home to a majority of the world's population-both agriculture and labor out-migration are considered the two primary livelihood strategies (World Bank Publications 2008; Jokisch 2002; de Haan 1999). Additionally, remittance the migrants send home has increasingly emerged as a major share of the national gross domestic product (GDP), sometimes leading to a remittance-dependent economy. Thus, understanding the relationship 
between changes in rural agriculture-particularly the use of farm technology—and outmigration will provide important insights that are especially valuable for policy-makers in their effort to reduce poverty and achieve their national development goals (de Brauw 2010; de Haan 1999; Taylor and Martin 2001).

Although new knowledge linking out-migration to agricultural change is important to achieve poverty reduction and national development goals, the analytical challenges and data requirements, including detailed measures of both agriculture and out-migration with appropriate temporal order, have limited the ability of previous research to adjudicate these relationships. By conducting rigorous empirical tests of the labor substitution hypothesis with panel data spanning more than 4-and-a-half years of uniquely detailed measures of both agricultural change and out-migration, we begin to address this gap in the literature and provide insight to policy-makers.

Our theoretical framework uses substitution of farm labor by modern farm technologies as the key intervening link between rural agricultural change and outmigration (Boserup 1965; Rauniyar and Goode 1996). Technological innovations such as mechanization, high-yielding crop varieties, improved animal breeds, chemical fertilizers and pesticides and development of new markets have dramatically changed the face of rural agriculture. This has led to the transformation away from subsistence farming towards commercial farming in many rural agrarian societies around the globe (Majumdar et al. 2001; World Bank Publications 2008). More recently, rural farm households are increasingly using farm technologies such as tractors, pumpsets, improved farm implements, and chemicals (fertilizers and pesticides). It is well established that these modern technologies are designed to perform labor-intensive jobs (Boserup 1965; 
Rauniyar and Goode 1996). Therefore, in accordance with the labor substitution effect, using such technologies has the potential to replace labor (Agarwal 1983; Binswanger 1978; Mamdani 1972; Rauniyar and Goode 1996), which may be consequential for individual out-migration. This framework, thus, has the advantage of explicitly situating the investigation in the local context, accounting for the important potential drivers of out-migration in rapidly changing agrarian societies.

This advancement is possible because the Chitwan Valley Family Study (CVFS) from south-central Nepal provides uniquely detailed measures of communities, households, and individuals along with measures of the use of modern farm technologies with precise temporal order. The data provide measures of a household's use of modern farm technologies in 1996, and prospective measures of household members' migration status with monthly precision for subsequent years. In addition, the rural agrarian setting of the western Chitwan Valley is ideal for this study because it is undergoing a dramatic transition away from subsistence farming — with a very low level of mechanization and no use of chemical fertilizers and pesticides - to a more commercialized farming system, with increasing dependency on mechanical technologies, chemical fertilizers, and pesticides. The data provide measures of multiple dimensions of farm inputs and technology use, along with a monthly record of migration from each household, thus offering an unusual opportunity to estimate the influence of modern technology use on out-migration. Considering farming and out-migration are two of the primary livelihood strategies in most poor agricultural settings, our study provides new insight into a crucial dimension of rural demographic change: out-migration.

\section{Theoretical Framework: Labor-saving Farm Technology Use and Out-migration}


Much of the existing literature on migration — both in theory and empirical evidence-focuses on socio-economic determinants of out-migration. For example, according to the neo-classical economic theory, migration is an attempt to gain higher wages or better living standards at one's destination (Massey et al. 1993; 1998). In this literature, migration is considered a cost-benefit decision; if expected conditions are better at the destination than place of origin and the additional earnings at the destination could offset the cost of migration, then people will migrate.

Similarly, the New Economics of Labor Migration (NELM) theory also focuses on economic factors. But according to NELM, the migration of individuals is a familybased decision and is an attempt to diversify household income portfolios to protect against risk and gain access to capital in order to finance consumer and productive purchases (Stark and Bloom 1985; Stark and Taylor 1991). If a household is in an area with imperfect markets and does not already own such items as a house, land, or business, the theory predicts that some individual household members will migrate. Other migration research focuses on theories of social networks and cumulative causation, introducing migration-specific capital as a key element in the decision to migrate. Social network theory focuses on the importance of interpersonal ties or migrant networks that help initiate or perpetuate migration. These networks facilitate the migration of individuals by lowering the associated costs (social, psychic and economic) and risks of movement (Massey et al. 1993). The cumulative causation theory highlights the promotion of chain migration and the perpetuation of migration, positing that as migration from an area becomes more common, the density of social connections between community members and those who have migrated can make migration an 
expected individual behavior and a self-sustaining community process (Massey 1990; Massey et al. 1993).

Migration research on environmental determinants focuses on the influences of environmental conditions such as decline in agricultural productivity, land-use and landcover change, deforestation, natural calamities and natural disasters on out-migration (Adamo 2009; Adamo and Crews-Meyer 2006; Gray 2009; Kalipeni 1996; Massey et al. 2010a; Myers 2002). Although these bodies of literature provide many insights into why people migrate, they capture only a modest part of the heterogeneity of populations that is relevant for migration and leave many important elements of migration decisions unexplained, including the influence of dramatic changes in rural agriculture, particularly the use of labor-saving technologies (labor substitution) on individual out-migration. Another stream of literature points toward plausible associations between the recent agricultural changes in poor rural communities, the major migrant sending areas, and out-migration. There is evidence indicative of the labor substitution effect by laborsaving modern farm technologies. Their use - particularly those designed to perform labor intensive jobs - act as a substitute for human labor and thus may have important implications in demographic studies including migration. In this study, we utilize this well-known but relatively untested labor substitution argument to explain individual outmigration. According to this argument, mechanization of agriculture decreases the need for manual labor and thus releases labor out of agriculture. The labor released thus creates a pool of mobile labor force of workers. One alternative livelihood strategy for the displaced labor could be to innovate or start a new business. However, as this requires time and initial capital for investment, which is scarce in the rural agrarian setting of most 
developing countries, the displaced labor will most likely migrate (Massey et al. 1998; Oberai 1984).

Traditionally, farming in rural agrarian societies is commonly performed by using human and animal labor. However, during the second half of the $20^{\text {th }}$ century world agriculture made a dramatic shift away from traditional farming systems towards increasingly mechanized, commercial farming systems (Majumdar et al. 2001; Mamdani 1972; Self 2008; Vosti et al. 1994; World Bank Publications 2008). Technological innovations (such as mechanization, high-yielding crop varieties, improved animal breeds, chemical fertilizers and pesticides) and development of new markets have dramatically changed the face of rural agriculture. This has led to the transformation away from subsistence farming towards commercial farming in many rural agrarian societies around the globe (Majumdar et al. 2001; World Bank Publications 2008). This transformation has led to dependence of rural subsistence farm households on modern farm technologies, including tractors, pumpsets, improved farm implements, and chemicals (fertilizers and pesticides).

Most modern technologies are designed to perform labor-intensive jobs (Boserup 1965; Rauniyar and Goode 1996). Thus, the fact that the use of such technologies has the potential to replace labor via the labor substitution effect (Agarwal 1983; Binswanger 1978; Mamdani 1972; Rauniyar and Goode 1996), may have important demographic implications including out-migration. For example, it is reported that tractors replace animal and human labor generally used in land preparation (Agarwal 1983; Biggs, Justice, and Lewis 2011; Binswanger 1978). For example, according to Agarwal (1983), using a tractor requires only one-fifth of the labor needed to plow the land compared to 
using a bullock. In addition, farmers are increasingly using farm implements such as corn shellers, threshers, sprayers and chaff cutters (Mamdani 1972; Pariyar, Shrestha and Dhakal 2001), which, when used altogether, replace the need for human labor. Evidence from India, for example, suggests that mechanical threshing of wheat reduces about 71 man-hours per hectare of land (Binswanger 1978). There is strong evidence that the decline in demand for labor due to use of mechanical technologies (here, tractor and farm implements) reduces the value of labor, thus removing labor from agriculture.

Considering this evidence of the labor substitution or labor replacement effects of mechanical farm technologies, we posit that:

Hypothesis 1. The use of a tractor is associated with increased individual outmigration from households.

Hypothesis 2. The use of farm implements is associated with increased individual out-migration from households.

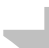
Moreover, farmers in rural agrarian societies commonly use farmyard manure (FYM) or compost for replenishing soil nutrients. However, more recently, farmers are increasingly using chemical fertilizers instead of manure or as a supplement to manure. Manure is generally applied by hand. Although fertilizer drills, seed drills, and row planters can also be used to apply chemical fertilizers, the most common practice is either by hand or by using a scoop and basket (Bartsch 1977). Unfortunately, comparative studies on the labor requirements of various methods of manure application are scarce and the available evidence is inconclusive. Anecdotal evidence, however, suggests that the application of FYM demands a much higher level of human labor compared to the use of chemical fertilizers. This is because producing manure requires a household to 
keep livestock, which necessitates a regular supply of labor required for livestock care and management. This includes the cleaning of the household's barn, preparation of compost, and transport and application of compost in the field. These tasks require a significant amount of labor in contrast to buying, storing, and applying chemical fertilizer. Therefore, we hypothesize that:

\section{Hypothesis 3. The use of a chemical fertilizer is associated with increased} individual out-migration from households.

Similarly, the use of pesticides (herbicides and insecticides) can also replace manual labor. Herbicides are used for controlling weed growth in crop fields, and insecticides and pesticides are used for controlling insects and diseases. Rani and Malavia (1992) report that one acre of land requires 12.42 days of manual weeding. However, with herbicide application, the time required for weed control decreases to 0.42 days per acre. Therefore, we hypothesize that:

Hypothesis 4. The use of pesticides is associated with increased individual outmigration from households.

\section{Methods}

\section{Study Setting}

This study was done in in the Western Chitwan Valley in south-central Nepal. This valley provides an ideal setting to test our hypothesis. Before the 1950 s, the valley was primarily covered with dense forests and was infamous for malarial infestation. In 1956 His Majesty's Government of Nepal, in collaboration with the United States government (International Cooperation Assistance), implemented a malaria eradication program and distributed land parcels to people coming from adjoining districts of the country. The flat 
terrain with its highly fertile soil and warm climate offered promising opportunities for people who were struggling with the steep mountain slopes. Chitwan, once known as a "death valley" soon became a melting pot, receiving people from all over the country. Consequently, as shown in Figure 1, the population of Chitwan grew very rapidly starting in the 1960s (much more than one can expect from natural fertility). Recently, Chitwan has experienced dramatic changes in population mobility, transitioning from a frontier destination for in-migrants from surrounding hill districts of Nepal to one of the country's major migrant-sending districts.

(Figure 1 about here)

Despite a massive expansion of schools, health services, markets, bus services, cooperatives, and employment centers in Chitwan (Axinn and Yabiku 2001), farming remains the primary source of livelihood in the valley. A large majority of farmers practice mixed-farming with highly integrated crop-livestock production systems, which remains largely subsistence in nature. A survey conducted by the Chitwan Valley Family Study (CVFS) in 1996 identified over 82 percent of households as farming households. About three-fourths of them kept cattle, buffalo, sheep and goats. Households cultivate land to produce food grains and raise livestock for animal protein (milk, meat and eggs), draft power, and manure. Rice, wheat, maize, mustard, pulses, buckwheat and sesame are the most important crops of the valley farming system. To a large extent, the labor needed for performing both farm and a non-farm activity originates within the household. More recently, the valley has been experiencing dramatic changes in agricultural systems; particularly transitioning from a subsistence-based farming system to a more commercial farming system with increasing use of modern farm technologies. The family 
mode of agricultural production is also rapidly changing throughout the valley. Land use systems have been highly intensified. For example, changes have been observed in the cropping systems, transitioning from what was once a dominant rice-wheat-maize system to the current rice-vegetable-maize system (Paudel et al. 2014). The use of modern farm technologies such as tractors, chemicals, irrigation and hybrid seeds is also increasing (Adhikari 2013; Bhandari and Ghimire 2013). For example, the CVFS (household agriculture and consumption surveys, 2001 and 2006) indicated that while only 79 percent of farm households reported use of chemical fertilizers in 2001, nearly 90 percent of farm households surveyed in 2006 reported such use in the past year. Similarly, the proportion of households that reported the use of pesticides (herbicides or insecticides) in crop production increased from 21 percent in 2001 to 32 percent in 2006 . On the other hand, the out-migration of individuals has also become a common phenomenon in the valley. The 2011 census reported that 29 percent of households in Chitwan had a household member living away, compared to 25 percent in the country as a whole (Central Bureau of Statistics 2012).

\section{Data}

This study used the individual-, household- and community-level data from multiple surveys collected by the Chitwan Valley Family Study (CVFS). The purpose of the CVFS was to examine the influence of rapidly changing social contexts on demographic processes including timing of marriage, childbearing, contraceptive use, and migration. The study was also designed to investigate the reciprocal relationships between family formation (marriage, childbearing, and migration) and environmental outcomes such as land use. 
Data to test our hypotheses came from a study of 151 neighborhoods scattered throughout the Western Chitwan Valley. For the purposes of this study, a neighborhood was defined as a geographic cluster of five to fifteen households. These neighborhoods were selected in 1995 as an equal probability, systematic sample of neighborhoods in Western Chitwan (Barber et al. 1997). All the households inside the 151 neighborhoods were used for the study. We used data from the 1996 household census, 1996 household consumption and agriculture survey, 1996 individual survey and the ongoing monthly demographic events registry data collected for 54 months (4.5 years) since 1996.

The 1996 household census collected information on the age and gender of each person living in a household. This survey included all the individuals who ate and slept most of the time in a given household during the past six months. Altogether there were 1,583 households living inside the 151 neighborhoods. After the household census, the 1996 household agriculture and consumption survey was administered to collect information on farming activities at the household level. The data were collected from 1,269 farm households from 151 communities. Of particular interest to this study, the 1996 household consumption and agriculture survey recorded information on the farming status of each household and the use of various farm inputs and technologies such as tractors, pumpsets, chemical fertilizers, and pesticides (herbicides and insecticides), as well as farm implements in crop production, and other information such as the size of cultivated land, land ownership, livestock holding, ownership of a house plot, and house quality. The data were collected using a face-to-face interview technique featuring a carefully designed interviewer-assisted structured schedule with a 99 per cent response rate. 
Information on age, gender, caste/ethnicity, school enrollment, number of years of schooling, current wage, salaried job and previous migration experience come from the 1996 individual survey. The 1996 individual survey (including life history calendar) was administered to 4,646 individuals of ages 15-59 years living in 151 neighborhoods and their spouse irrespective of their residence within Nepal. For this study, however, we used data from 3,401 individuals of ages 15-59 years living in the households within 151 neighborhoods at the time of 1996 individual survey. Each individual contributed to the records until they experienced the event, here, out-migration. Out-migration was defined as, 'an individual living away from home (does not eat in the same kitchen and does not sleep in this home) most of the time in the past month. Individuals ceased contributing to the records after the event (out-migration) occurred. Other individuals were censured at the end of the observation window.

The ongoing monthly demographic event registry monitors demographic events such as marriage, child bearing, migration and deaths for every month since 1996. This study utilizes the information on individual out-migration as the outcome variable which was updated from the demographic event registry over a period of 54 months (4.5 years). This study utilized the previous migration experience of all individuals that were interviewed in 1996 individual survey and were living in farm households of 151 neighborhoods at the time of survey in 1996.

Other controls such as the number of non-family community services and the distance to the largest market center, Narayangarh, come from the neighborhood-level data (see Axinn, Barber and Ghimire 1997 for details).

\section{Measures}


First-time Out-migration. Out-migration is defined as any departure from the neighborhood lasting one month or more for any reason; it includes moving within and outside of Nepal. This measure captures first-time out-migration of individuals over a period of 54 months after household agriculture and consumption survey of 1996. We implemented a one-month interval to capture seasonal migration. The measure of firsttime out-migration is coded " 1 " in the month that person migrates, and " 0 " otherwise. This measure comes from the monthly demographic event history data.

(Table 1 about here)

Fifty-one percent of individuals experienced a first time out-migration after household agriculture and consumption survey in 1996 during a period of 54 months (4.5 years). Kaplan-Meier survival curves for technology use and out-migration are presented in figures 2 to 5 to explore the migration experience of individuals who lived in a household that used a farm technology and those who did not use them (Allison, 2010). The results, in general, show that the rate of migration for individuals whose household used a farm technology is faster that those whose household did not use a farm technology. For example, 20 percent [(2610-2097/2610)*100)] of individuals from households that used a tractor in 1996 experienced out-migration within the first 10 months compared to only 17 percent $\left.\left[(791-655 / 791)^{*} 100\right)\right]$ of individuals that did not use a tractor.

(Figure 2 about here)

Similarly, the rate of migration for individuals whose household used farm implements, chemical fertilizer and pesticides are provided in figures 3 to 5 respectively. Except individuals from tractor using households, differences in the rate of migration 
between the user and nonuser of farm implements, chemical fertilizer and pesticides are not statistically significant (both Log-Rank and Wilcoxon tests).

(Figures 3-5 about here)

Technology Use. Uses of modern farm technologies such as tractors, farm implements, chemical fertilizers, and pesticides in crop production by a farm household by 1996 are the major explanatory variables. These are the household-level measures and come from the 1996 household consumption and agriculture survey. Importantly, these measures were collected in 1996 prior to the measurement of the outcome measure of out-migration. These data provide a unique analytical opportunity to examine the effects of labor-saving technology use in crop production on subsequent out-migration.

Tractors use. Use of a tractor by a farm household was measured with a survey item "Did your household use a tractor to plough the land for planting ..... crop?" This measure is dichotomously coded " 1 " if the household used a tractor and " 0 " otherwise. 1 Farm implements. Ownership of modern farm implements has been considered an indicator of farm implement use. We asked, "Does your household have a thresher, chaff cutter, sprayer, corn sheller, or any other kind of farm tools?" This measure was coded " 1 " if a household owns any of the farm implements and " 0 " otherwise.

Chemical fertilizers and pesticides. Use of chemical fertilizers was measured by asking, "Did you use chemical fertilizer in the past three years?" A similar question was asked for pesticide use which includes herbicides or insecticides. The measure was dichotomously coded " 1 " if a household used any of the products and " 0 " otherwise. As there is a low correlation between the uses of these two measures, we used them separately in the analysis. 
Modern technology use in crop production varied greatly over this time period (Table 1). While 77 percent of individuals lived in farm households that reported the use of a tractor for land preparation, only 17 percent of individuals lived in a household that owned any modern farm equipment such as a thresher, chaff cutter, sprayer, corn sheller, or other implements. Eighty-four percent of individuals lived in households that reported the use of chemical fertilizers and about 24 percent lived in households that reported the use of pesticides (herbicides or insecticides).

Controls. Since individual out-migration and farm technology use are influenced by a large array of individual-, household- and community-level factors, we also included a series of controls known to shape this relationship. To estimate the net effects of farm technology use on out-migration, we used previously tested measures of human capital, social capital, and physical capital in this setting (Massey et al. 2010a). We also included demographic controls such as age, gender, household size and caste/ethnicity. These controls were measured in 1996. Human capital. Measures of human capital included: (a) whether the individual was enrolled in school, (b) number of years of schooling, (c) if s/he currently has a wage job, and (d) if s/he currently has salaried job. We also control for an individual's migration experience as number of years outside Chitwan before the household agriculture and consumption survey in 1996. This measure includes both within and outside Nepal migration experience. These measures were derived from 1996 individual life history calendar, a part of the 1996 individual survey. Seventeen percent of individuals reported current enrollment in school. Close to six years was the average number of years of schooling obtained by individuals in this study. Thirty six percent of 
individuals held a waged job and only 8 percent held a salaried job.

Social capital. Measures of social capital included: (a) whether a household had a network tie, measured by the presence of at least one other household member with migratory experience, and (b) neighborhood migration prevalence, measured by the relative proportion of persons within the neighborhood who migrated in the past. These measures were derived from the individual survey aggregated at the neighborhood level. Fifty-eight percent of individuals lived in a household that reported a network tie; at least one household member was a migrant. The average proportion of households with a migrant in the community, also called neighborhood prevalence, was 23 percent. Physical capital. Measures of physical capital include (a) access to a market (in minutes walked to the nearest market), (b) ownership of farm land and livestock, (c) ownership of a house plot, and (d) home quality - an index of house quality ranging from 4-18 (poor to better quality, please refer to Massey et al. 2010). These measures were derived from the 1996 household agriculture and consumption survey. The average walking distance to the nearest market from the household was 1.97 minutes (logged). Ninety four percent of individuals lived in households that owned some land or a household plot. The average number of animals in the household was 2.98 (livestock standard unit). The average index of home quality was 9 (in a range of 4-18). Demographic controls include gender, age, individual migration experience prior to 1996, household size, and caste/ethnicity. Gender is a dichotomous measure (male/female). Age is categorized into four birth cohorts (ages 15-24; 25-34; 35-44; 45 59). Caste/ethnicity is measured as: (a) Brahmin/Chhetri, (b) Dalit, (c) Hill Janajati (e.g. Tamang, Gurung, and Magar), (d) Newar, and (e) Terai Janajati (e.g. Tharu, Derai and 
Kumal). These individual level measures were derived from 1996 individual survey.

Household size is measured as the number of individuals living at the time of the 1996 census. Overall, 56 percent of individuals were females and more than 60 percent of individuals were aged 34 or under. On average, an individual had over 9 years of experience outside of Chitwan district prior to 1996. In terms of caste/ethnicity, about half (49 percent) were Brahmin/Chhetri, 10 percent were Dalit, 14 percent were Hill Janajati, 6 percent were Newar, and 21 percent were Terai Janajati. The average size of the household was 6.74 individuals.

\section{Analytic Strategy}

We used the following analytical strategy. First, we calculated the univariate distribution of all measures used in the analysis. We also produced Kaplan-Meier (also called product-limit estimator) survival curves to show the survivor functions between technology use and out-migration over time (Allison 2010). Then, we estimated multivariate models using multilevel discrete-time event history methods to model the monthly hazard of out-migration, with person-months serving as the unit of analysis. This modeling strategy is appropriate because the probability of out-migration is so small within each one-month interval, the estimates from discrete time methods are extremely similar to those that would be obtained using comparable continuous time models (Peterson 1991). These models were estimated using the GLIMMIX macro of SAS (Barber et al., 2000) (Table 2) ${ }^{1}$. This strategy takes into account of clustering of

\footnotetext{
${ }^{1}$ We also estimated multivariate models using Cox proportional hazard modeling technique in SAS with the option of COVS (AGGREGATE) in the PROC PHREG statement, and using the ID statement to indicate that observations with the same ID (in this study are neighborhoods) are from the same cluster (Ying and Liu 2008; Lee, Wei and Amato, 1992; SAS Institute Inc. 2013; Lin, and Wei 1989). While the magnitudes of the coefficients were very similar, the strength of significance ( $p$-values) slightly
} 
individuals (level 1), here migrants, by geographic clusters (here neighborhoods or communities) (level 2) (Garson, 2013). This procedure produces a multilevel hazard model that accounts for the clustering of individuals in our sample by community. We first estimated the effect of each farm technology separately (models 1-4) and then used all of them simultaneously in the equation in a single model (model 5). In each model, we adjusted for the effects of all other controls.

\section{Results}

Results of multivariate analysis are presented in the order outlined in the theoretical framework (Table 2). The results are presented as odds ratios of first time out-migration after the 1996 individual survey from the communities of Chitwan Valley, Nepal. Guided by a nested modeling strategy, we began with a simple model of a single technology use with a basic set of controls (Models 1 - 4). In Model 5, we simultaneously include all four measures of technology use to estimate their independent effects on individual outmigration.

(Table 2 about here)

First, we examined the results of the fit statistics. The results of the commonly used fit statistics (AIC, BIC and -2 log likelihood) for all models (models 1-5) are smaller than the statistics of the null model (intercept only model) implying that the results are good fit (Garson 2013). Then, we examined the effects of the controls first, which allow examination of the internal validity of our controls and provide the basis for

decreased in the Cox proportional hazard method as compared to the discrete-time event history method. However, we used the results from original modeling strategy. Because the probability of out-migration is so small within each one-month interval, the estimates from discrete time methods are extremely similar to those that would be obtained using comparable continuous time models (Peterson 1991). 
generalizability of our results. In general, the effects of most of the controls included in the models were as expected. For example, education has a positive effect on outmigration; females are less likely to migrate than their male counterparts; younger individuals are more likely to migrate than older individuals; household networks (household had a network tie), neighborhood migration prevalence and previous migration experience positively influenced out-migration. Additionally, compared to the Brahmin/Chhetri group, Hill Janajati and Dalit are more likely to migrate, whereas those from Terai Janajati and Newar are less likely to migrate. As expected, both the ownership of a house plot and the quality of a home significantly reduced the rate of out-migration. The number of large animals owned by a household also reduced the likelihood of individual out-migration These results are consistent with the previous findings from Nepal and, specifically, the region we study (Bhandari 2004; Massey et al. 2010a;

Piotrowski 2010; Piotrowski et al. 2013). This suggests the internal validity of our results, increasing confidence in our findings on the relationships between farm technology use and individual out-migration. Now, we discuss the results of the effects of the major explanatory factors technology use on the rate of out-migration. Tractor Use and Out-migration. Model 1 of Table 2 displays the effect of a farm household's tractor use for land preparation on individual out-migration. The results suggest that a household's use of a tractor has a strong, positive, statistically significant effect on individual out-migration net of all other controls. The results indicate that compared to individuals who lived in a household that did not use a tractor for agriculture, individuals living in households that used a tractor migrated at a rate 24 percent higher (odds ratio $=1.24 ; \mathrm{p}<.01)$. This effect is consistent with the labor 
substitution hypothesis that the individuals living in a household that used a labor-saving technology are most likely to migrate. For instance, we argued that modern technologies are designed to perform labor-intensive jobs (Boserup 1965; Rauniyar and Goode 1996) and therefore, their use has the potential to replace labor via the labor substitution effect (Agarwal 1983; Binswanger 1978; Mamdani 1972; Rauniyar and Goode 1996). The labor substitution is mainly due to the decline in demand for labor due to use of labor-saving technologies. The resulting surplus labor in the absence of alternative employment opportunities as well as sources of income out-migrated in search of alternative livelihood strategies.

Farm Implements Use and Out-migration. Model 2 of Table 2 displays the effect of a farm household's farm implement use on the rate of individual out-migration. The result is not statistically significant, however.

Use of Chemical Fertilizer and Pesticide Use and Out-migration. Models 3 and 4 of Table 2 provide estimates of the individual effects of chemical fertilizer and pesticide use on out-migration, respectively. The results, however, are not statistically significant. Independent Effects of Technology Use on Out-migration. Finally, in Model 5 of Table 2, all four measures of technology use are simultaneously included in a single model. The results indicate no substantial change in the effects of the measures of technology use on out-migration independent of all other controls. The effects in this full model remain similar to that of the single models (Models $1-4$ ). The results suggest that the use of a tractor influences individual out-migration independent of other farm technologies. This investigation finds substantial and statistically significant independent effects of key dimensions of mechanical technology use with tractor use specifically. But 
other farm technologies are not statistically significantly important in the out-migration decision-making process.

\section{Discussion and Conclusion}

Recently, migration has become a common phenomenon with more people now living in destinations outside of their birth place and country than at any time in human history.

Agricultural households from rural agrarian countries have become the major sources of this mobile population. Concurrently, rural subsistence-based agrarian households are rapidly changing towards greater commercialization and are adopting modern agricultural practices such as mechanization, and the use of chemical fertilizers and pesticides designed to save labor. At this juncture, we examine whether the uses of labor-saving farm technologies contributed to the rate of individual out-migration in an agrarian setting. Our results provide important insights into the pace of out-migration in rural agrarian societies with an important theoretical and practical significance for populations in Nepal and in similar settings around the globe.

Using unique panel data from Chitwan Valley, Nepal—a rapidly changing subsistence-based rural agricultural setting — our results provide evidence of a positive association between agricultural mechanization — particularly tractor use — and individual out-migration independent of various community-, household-, and individual-level factors known to influence migration. As hypothesized, the findings suggest that the use of a tractor positively influences individual out-migration. The use of a tractor may have replaced the labor required for plowing the land. As expected, this mechanization of agriculture may have decreased the need for manual labor and the laborers released out of agriculture may have migrated elsewhere (Oberai 1984; Massey et al. 1998). 
Interestingly, however, we did not find any significant effects of the uses of chemical fertilizers, pesticides and improved farm implements on individual outmigration. There are several potential explanations. One possible reason is that farmers in the valley continue to use FYM along with chemical fertilizers. In a fertilizer use study conducted in 2003 by Nepal's Ministry of Agriculture and Cooperatives (2003), about 81 percent of households used both chemical fertilizers and FYM in Nepal. Another reason behind their apparent lack of effect on out-migration could be due to gender-specific labor replacement by these farm implements and chemicals. In Nepal, application of farmyard manure, weeding, and thinning out of disease- and insect-infested plants are primarily performed by women, who are less likely to migrate. Therefore, the use of chemical fertilizers and pesticides may have replaced women's labor, which may not have strong effects on out-migration — particularly males — suggesting a gender disaggregated analysis as a potential future direction for this line of research. (1) While this study addresses gaps in previous research, it also raises theoretically relevant and practically significant questions. Theoretically, as out-migration perpetuates, two opposing conditions, particularly in agriculture, are typically postulated (Jokisch 2002). Some scholars believe that the loss of labor due to out-migration threatens the capacity of households to respond to labor demands, leading to a decline in crop cultivation and agricultural production (Mines and de Janvry 1982; Black 1993). Moreover, migration may also lower agricultural production if households substitute remittances for an agricultural income (Ferran and Pessar 1990) or if remittances are sufficiently large enough to permit households to stop farming (Momsen 1986). On the other hand, although somewhat inconclusive, other scholars believe that the remittances 
due to migration may overcome labor shortfalls and provide capital inputs to make agricultural improvements. This may occur by encouraging investments in agricultural improvement including agricultural technology use, supporting the New Economics of Labor Migration (NELM) theory (Jokisch 2002; Mendola 2008; Pant 2008; Quinn 2009; Rivera 2005; Seddon 2004; Sharma and Gurung 2009; Stark and Bloom 1985). Although our study provides evidence of the effect of the uses of labor saving technologies (particularly the use of a tractor) in initiating individual out-migration, issues related to the future of agriculture remain unanswered.

Our study has its own limitations which provide direction for future work. First, from a methodological perspective, the explanatory variables and the controls were measured in 1996 and are held static at the 1996 level. However, the strength of this study is that the explanatory measures and controls occurred and were measured prior to the outcome measure, the first time out-migration, which is time varying and measured up to 54 months since the individual interview in 1996. Second, this investigation was unable to control for whether a household shares or hires labor for agricultural operations as another viable alternative to labor-saving technology use. Our survey lacks this particular measure. Third, the findings are based on data from only one part of the southern Terai plain of Nepal and therefore may not be generalizable to other rural areas. Fourth, a related limitation is that the finding regarding mechanical farm technology use may not be an appropriate foundation for country-wide policies, as it is difficult to use machines, such as tractors, in the hills and the mountains of Nepal due to topographical difficulties. This suggests the need for further studies in other parts of the country while taking into account geographical terrain. 
Moreover, from a societal perspective, there are controversies about the benefits of modern farm inputs and technology use worldwide. The consequences of the green revolution technologies including farm mechanization are likely to go beyond migration. For example, the results of the shift from traditional farming to commercial farming in peasant economies may include unequal distribution of economic benefits (Cleaver 1972; Griffin 1974; Jacoby 1972), unemployment (Griffin 1974; Jacoby 1972), and possible peasant revolutions (Paige 1975; Scott 1977; Skocpol 1982; Wolf 1969). Scholars have also argued that agricultural modernization or the use of modern farm technologies mostly benefit large farmers (Griffin 1974; Jacoby 1972). Jacoby (1972) believes that the green revolution has not resulted in socio-economic development-particularly in South Asia-but rather has shaken the economic foundation of the agricultural population in these countries. It is argued that the rural poor do not receive a fair share of the benefits generated from the green revolution. These issues require careful examination. Additionally, further consideration is required to understand the environmental effects of technology use. For example, from an environmental perspective, the uses of chemical fertilizers and pesticides may jeopardize the environment by leaching chemicals into water bodies, poisoning food, and damaging insects and pests (Biswas 1994; Pimentel and Pimentel 1991). Similarly, the use of oil-based farm technologies (such as tractors) may have serious environmental consequences impacting carbon emissions and global climate change (Hill et al. 2009).

Although the technological revolution — which includes agricultural modernization - significantly influences both human populations and the global environment with important consequences, due to the modest scope of this paper we 
focused only on one specific demographic consequence: individual out-migration.

Therefore, the paper does not address other concerns. Moreover, the consequences of the uses of these labor-saving farm technologies on various aspects of the economy, society (including gender relations; human fertility, population health), and the environment must be considered before formulating any policy, which is in itself a formidable challenge.
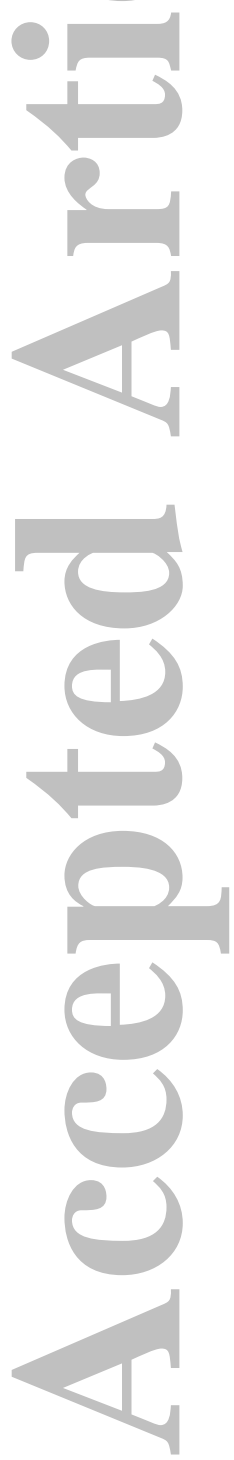


\section{References}

Adamo, Susana B. 2009. Environmentally Induced Population Displacements. IHDP Update 1.2009. Retrieved on July 1, 2015 (http://www.ciesin.org/documents/environinduced-s.adamo-IHDPupdate2009.pdf)

Adamo, Susana B., and Kelly A. Crews-Meyer. 2006. “Aridity and Desertification:

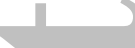
Exploring Environmental Hazards in Ja'chal, Argentina.” Applied Geography 26(1):61-85.

Adhikari, Jagannath. 2013. "Changes in Chitwan." The Kathmandu Post. November 20. Retrieved March 26, 2015 (http://www.ekantipur.com/the-kathmandu post/2013/11/19/related articles/change-in-chitwan/255969.html).

Agarwal, Bina. 1983. Mechanization in Indian Agriculture: An Analytical Study Based on the Punjab. New Delhi: Allied Publishers Private Limited.

Axinn, William G., Jennifer S. Barber, and Dirgha J. Ghimire. 1997. “The Neighborhood History Calendar: A Data Collection Method Designed for Dynamic Multilevel Modeling.” Sociological Methodology 27(1):355-392.

Axinn, William G., and Scott Yabiku. 2001. "Social Change, the Social Organization of Families, and Fertility Limitation.” American Journal of Sociology 106(5):12191261.

Barber, Jennifer S., Susan A. Murphy, William G. Axinn, and Jerry Maples. 2000. “Discrete-time Multilevel Hazard Analysis.” Sociological Methodology 30(1):201-235.

Barber, Jennifer S, Ganesh P. Shivakoti, William G. Axinn, and Kishor Gajurel. 1997. 
"Sampling Strategies for Rural Settings: A Detailed Example from the Chitwan

Valley Family Study, Nepal.” Nepal Population Journal 6(5):193-203.

Barber, Jennifer S., Susan A. Murphy, William G. Axinn, and Jerry J. Maples. 2000.

"Discrete-Time Multilevel Hazard Analysis." Sociological Methodology 30:201235.

Bartsch, William H. 1977. "Employment and Technology Choice in Asian Agriculture.”

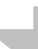
Revue Tiers Monde 18(71):691.

Bhandari, Prem. 2004. "Relative Deprivation and Migration in an Agricultural Setting of Nepal." Population and Environment 25(5):475-499.

Bhandari, Prem, and Dirgha Ghimire. 2013. "Rural Agricultural Change and Fertility Transition in Nepal.” Rural Sociology 78(2):229-252.

Biggs, Stephen, Scott Justice, and David Lewis. 2011. "Patterns of Rural Mechanization, Energy and Employment in South Asia: Reopening the Debate." Economics and Political Weekly XLVI (9):78-82.

Bilsborrow, Richard E. 1992. "Population Growth, Internal Migration, and Environmental Degradation in Rural Areas of Developing Countries.” European Journal of Population 8(2):125-148.

Bilsborrow, Richard E. 2002. "Migration, Population Change and the Rural Environment." ESCP Report (8):69-94.

Binswanger, Hans P. 1978. The Economics of Tractors in South Asia. New York:

Agricultural Development Council and Hyderabad, India: International Crops Research Institute for the Semi-Arid Tropics. Retrieved July 1, 2015 (http://oar.icrisat.org/630/1/RA_000005.pdf). 
Biswas, Margaret R. 1994. “Agriculture and Environment: A Review, 1972-1992.” Ambio 23(3):192-97.

Black, Richard. 1993. "Migration, Return, and Agricultural Development in the Serra do

Alvao, Northern Portugal.” Economic Development and Cultural Change 41(3):563-585.

Boserup, Ester. 1965. The Conditions of Agricultural Growth: The Economics of (1) Agrarian Change under Population Pressure. Chicago: Aldine Publishing Company.

Boserup, Ester. 1990. Economic and Demographic Relationships in Development: Essays Selected and Introduced by T. Paul Schultz. Baltimore and London: The Johns Hopkins University Press.

Central Bureau of Statistics. 2012. National Population and Housing Census 2011 National Report. Kathmandu: National Planning Commission Secretariat, $\sqrt{10}$ Government of Nepal.

Cleaver, Harry M. 1972. "The Contradictions of the Green Revolution." American Economic Review 62(1/2):177-88.

de Brauw, Alan, J. Edward Taylor, and Scott Rozelle. 1999. “The Impact of Migration and Remittances on Rural Incomes in China.” Paper presented at the 1999 American Agricultural Economics Association Annual Meetings, August 8-11, Nashville, TN.

de Brauw, Alan. 2010. "Seasonal Migration and Agricultural Production in Vietnam." The Journal of Development Studies 46(1):114-139. de Haan, Arjan. 1999. "Livelihood and Poverty: The Role of Migration - a Critical 
Review of the Migration Literature." The Journal of Development Studies $36(2): 1-47$.

Ecer, Sencer, and Andrea Tompkins. 2010. “An Econometric Analysis of the Remittance Determinants Among Ghanaians and Nigerians in The United States, United Kingdom, and Germany.” International Migration 51(s1):e53-e69.

Ferran, Fernando, and Patricia R. Pessar. 1990. "Dominican Agriculture and the Effect of



International Migration, Working Paper \#29.” Commission for the Study of

International Migration and Cooperative Economic Development.

Garson, G. David. 2013. "Fundamentals of Hierarchical Linear and Multilevel

Modeling." Hierarchical Linear Modeling: Guide and Applications. Los

Angeles, London, New Delhi, Singapore, Washington DC: Sage Publications Inc, pp. 3-26.

Gray, Clark L. 2009. "Rural Out-migration and Smallholder Agriculture in the Southern .

Ecuadorian Andes.” Population and Environment 30(4-5):193-217.

Griffin, Keith. 1974. The Political Economy of Agrarian Change. London: Macmillan. Hill, Jason, Stephen Polasky, Erik Nelson, David Tillman, Hong Huo, Lindsay Ludwig, James Newmann, Haochi Zheng, and Diego Bonta. 2009. “Climate Change and Health Costs of Air Emissions from Biofuels and Gasoline." Proceedings of the National Academy of Sciences of the United States of America 106(6):2077-2082.

Hunter, L. M. 2005. "Migration and Environmental Hazards.” Population and Environment 26(4): 273-302.

IOM (International Organization for Migration). 2010. World Migration Report 2010 The Future of Migration: Building Capacities for Change. Geneva: IOM. 
Retreived July 1, 2015

(http://publications.iom.int/bookstore/free/WMR_2010_ENGLISH.pdf)

Jacoby, Erich H. 1972. "Effects of 'Green Revolution' in South and South-East Asia." Modern Asian Studies 6(1):63-69.

Jokisch, Brad D. 2002. "Migration and Agricultural Change: The Case of Smallholder Agriculture in Highland Ecuador." Human Ecology 30(4):523-550.

Kalipeni, Ezekiel. 1996. "Demographic Response to Environmental Pressure in Malawi." Population and Environment 17(4):285-308.

Koc, Ismet, and Isil Onan. 2004. 'International Migrants' Remittances and Welfare Status of the Left-behind Families in Turkey." International Migration Review $38(1): 78-112$.

Lee, Eric W, L. J. Wei and David A Amato. 1992. “Cox-type Regression Analysis for Large Numbers of Small Groups of Correlated Failure Time Observations.” $\sqrt{10}$ Survival Analysis: State 01 the Art, 237-247.

Lin, D. Y. and Wei, L. J. 1989. The Robust Inference for the Proportional Hazards Model." Journal of the American Statistical Association, 84:1074-1078.

Majumdar, Prasanta K., Dilip K. Dolui, and Hiron K. Banerjee. 2001. "Child Labour, Education and Fertility." Paper presented at the International Union for the Scientific Study of Population, August 18-24, Salvador, Brazil.

Mamdani, Mahmood. 1972. The Myth of Population Control: Family, Caste, and Class in an Indian Village. New York and London: Monthly Review Press.

Massey, Douglas S. 1990. "Social Structure, Household Strategies, and the Cumulative Causation of Migration.” Population Index 56(1):3-26. 
Massey, D. S., J. Arango, G. Hugo, A. Kouaouci, A. Pellegrino, and J. E. Taylor. 1993. Theories of International Migration: A Review and Appraisal. Population and Development Review 431-466.

Massey, Douglas S., William G. Axinn, and Dirgha J. Ghimire. 2010a. "Environmental Change and Out-Migration: Evidence from Nepal." Population and Environment 32(2-3):109-136.

Massey, Douglas S., Nathalie Williams, William G. Axinn, and Dirgha J. Ghimire. 2010b. "Community Services and Out-Migration." International Migration 48(3): $1-41$.

Massey, Douglas S., Joaquín Arango, Graeme Hugo, Ali Kouaouci, Adela Pellegrino, and J. Edward Taylor. 1998. Worlds in Motion: International Migration at the End of the Millennium. Oxford: Oxford University Press.

Mendola, Mariapia. 2008. "Migration and Technological Change in Rural Households: Complements or Substitutes?" Journal of Development Economics 85(1-2):150175.

Mines, Richard, and Alain de Janvry. 1982. "Migration to the United States and Mexican Rural Development: A Case Study." American Journal of Agricultural Economics 64(3):444-454.

Ministry of Agriculture and Cooperatives. 2003. Nepal Fertilizer Use Study. A Study

Funded by the UK Department for International Development (DFID), Kathmandu, Nepal.

Momsen, J. 1986. "Migration and Rural Development in the Caribbean.” Tijdschrift Voor Economische en Sociale Geografie 77(1):50-58. 
Myers, N. 2002. Environmental Refugees: A Growing Phenomenon of the 21st Century. Philosophical Transactions of the Royal Society B: Biological Sciences 357(1420):609-613.

Oberai, A.S. 1984. "Migration, Production and Technological Change.” Migration Surveys in Low Income Countries: Guidelines for Survey and Questionnaire Design, edited by R. E. Bilsborrow, A. S. Oberai, and G. Standing. London and Sydney: Croom Helm, 317-373.

Paudel, B., B. S. Acharya, R. Ghimire, K. R. Dahal, and P. Bista. 2014. “Adapting Agriculture to Climate Change and Variability in Chitwan: Long-Term Trends and Farmers' Perceptions.” Agricultural Research 3(2), 165-174.

Paige, Jeffry M. 1975. Agrarian Revolution: Social Movements and Export Agriculture in the Underdeveloped World. New York: Free Press.

Pant, Bhubanesh. 2008. "Mobilizing Remittances for Productive Use: A Policy-oriented Approach.” NRB Working Paper No. 4. Nepal Rastra Bank, Research Department, Kathmandu, Nepal.

Pariyar, Madan, Khadga Bahadur Shrestha, and Narahari Dhakal. 2001. "Baseline Study on Agricultural Mechanization Needs in Nepal.” Facilitation Unit, Rice-Wheat Consortium for the Indo-Gangetic Plains. New Delhi, India: National Agricultural Science Centre (NASC) Complex, DPS Marg, Pusa Campus.

Peterson, Trond. 1991. "The Statistical Analysis of Event Histories.” Sociological Methods and Research 19: 270-323.

Pimentel, D and M. Pimentel. 1991. "Comment: Adverse Environmental Consequences of the Green Revolution.” Population and Development Review 16 (Supplement: 
Resources, Environment, and Population):329-332. Piore, M. J. 1979. Birds of Passage: Migrant Labor in Industrial Societies. New York: Cambridge University Press.

Piotrowski, Martin, Dirgha J. Ghimire, and Ronald Rindfuss. 2013. "Farming Systems and Rural Out-Migration in Nang Rong, Thailand, and Chitwan Valley, Nepal." Rural Sociology 78(1):75-108.

Piotrowski, Martin. 2013. "Mass Media and Rural Out-Migration in the Context of Social Change: Evidence from Rural Nepal." International Migration. 51(3):169-193.

Piotrowski, M., and Y. Tong. 2010. "Economic and Non-economic Determinants of Return Migration: Evidence from Rural Thailand." Population, English edition, 65(2): 333-348.

Quinn, Michael A. 2009. "Estimating the Impact of Migration and Remittances on Agricultural Technology.” The Journal of Developing Areas 43(1):199-216.

Rani, Seema and A. Malaviya. 1992. "Farm Mechanization and Women in Paddy Cultivation.” Pp. 261-67 in Women in Agriculture: Their Status and Role, Vol. 1, edited by R. K. Punia. New Delhi: Northern Book Center.

Rauniyar, Ganesh P. and Frank M. Goode. 1996. "Managing Green Revolution Technology: An Analysis of a Differential Practice Combination in Swaziland.” Economic Development and Cultural Change 44(2):413-37.

Rivera, Jose Jorge Mora. 2005. "The Impact of Migration and Remittances on Distribution and Sources Income: The Mexican Rural Case.” United Nations Population Division Working Paper. Population Division, Department of Economic and Social Affairs, United Nations Secretariat, New York. 
SAS Institute Inc. 2013. SAS/STAT® 13.1 User's Guide. Cary, NC: SAS Institute Inc.

Sjaastad, Larry A. 1962. "The Costs and Returns of Human Migration." Journal of Political Economy 70(5):80-93.

Scott, James C. 1977. The Moral Economy of the Peasant: Rebellion and Subsistence in Southeast Asia. New Haven: Yale University Press.

Seddon, David. 2004. "South Asian Remittances: Implications for Development." (1) Contemporary South Asia 13(4):403-420.

Self, Sharmistha. 2008. "Developing Countries and Fertility: Role of Agricultural Technology.” International Journal of Development Studies 7(1):62-75.

Shiva, Vandana. 1993. Monocultures of the Mind: Perspectives on Biodiversity and Biotechnology. Penang, Malaysia: Zed Books and Third World Network.

Skocpol, Theda. 1982. "Review: What Makes Peasants Revolutionary?" Comparative Politics 14(3):351-75.

Stark, Oded and D.E. Bloom. 1985. "The New Economics of Labor Migration.” American Economic Review 75(2):173-178.

Stark, Oded and J. Edward Taylor. 1991. "Relative Deprivation and Migration: Theory, Evidence, and Policy Implications.” Policy, Research, and External Affairs Working Papers No. 656, Welfare and Human Resources, The World Bank, Washington, D.C.

Stark, O., and D. Levhari. 1982. "On Migration and Risk in Ldcs." Economic Development and Cultural Change 31(1):191-96.

Stark, O., and J.E. Taylor. 1989. "Relative Deprivation and International Migration." Demography 26(1):1-14. 
Stard, O. 1991. "Migration Incentives, Migration Types: The Role of Relative Deprivation." The Economic Journal 101(408):1163-78.

Taylor, J. E., and P. L. Martin. 2001. "Human Capital: Migration and Rural Population Change." Handbook of Agricultural Economics 1: 457-511.

Taylor, J. Edward, Scott Rozelle, and Alan de Brauw. 2003. "Migration and Incomes in Source Communities: A New Economics of Migration Perspective from China.” Economic Development and Cultural Change 52(1):75-101.

Taylor, J.E. 1986. "Differential Migration, Networks, Information, and Risk." Migration, Human Capital, and Development, edited by O. Stark. Greenwich, CT: JAI Press, 141-171.

Taylor, J.E. 1987. "Undocumented Mexico_-U.S. Migration and the Returns to Households in Rural Mexico." American Journal of Agricultural Economics 69(3):629-38.

Todaro, Michael P. 1969. "A Model of Labor Migration and Urban Unemployment in Less Developed Countries." American Economic Review 59(1):138-48.

Todaro, Michael P., and Lydia Maruszko. 1987. "Illegal Migration and Us Immigration Reform: A Conceptual Framework." Population \& Development Review 13(1):1987.

UN Press Release. 2013. "Number of International Migrants Rises above 232 Million.” High-level Dialogue on International Migration and Development. Making Migration Work. Department of Economic and Social Affairs. United Nations. Retrieved October 23, 2013 (http://www.un.org/en/development/desa/news/population/number-of- 
international-migrants-rises.html).

Vosti, Stephen A., Julie Witcover, and Michael Lipton. 1994. "The Impact of Technology Change in Agriculture on Human Fertility: District-level Evidence from India.” EPTD Discussion Paper No. 5. International Food Policy Research Institute, Washington, D.C.

Wallerstein, Immanuel. 1974. The Modern World System. Capitalist Agriculture, and the In

Origins of the European World Economy in the Sixteenth Century. New York: Academic Press.

Wolf, Eric R. 1969. Peasant Wars of the Twentieth Century. New York: Harper and Row. World Bank Publications. 2008. World Development Report 2008: Agriculture for Development, Washington, D.C.

Yabiku, Scott T. 2004. "Marriage Timing in Nepal: Organizational Effects and Individual Mechanisms.” Social Forces 83(2):559-86.

Ying, Gui-shuang and Chengcheng Liu. 2006. Statistical Analysis of Clustered Data using SAS ${ }^{\circledR}$ System. NESUG. Analysis. Center for Preventive Ophthalmology and Biostatistics, University of Pennsylvania. (Retrieved on October 29, 2015, http://www.lexjansen.com/nesug/nesug06/an/da01.pdf). 
Table 1. Definitions, Means and Standard Deviations of Measures in the Analysis of Farm Technology Use and First Time Out-migration in Chitwan Valley, Nepal $(\mathrm{N}=\mathbf{3 , 4 0 1})$.

\begin{tabular}{|c|c|c|c|}
\hline Measures & Definition & Mean & SD \\
\hline \multicolumn{4}{|l|}{ Outcome } \\
\hline First-time out-migration & 1 if migrated, 0 otherwise & 0.51 & 0.47 \\
\hline \multicolumn{4}{|l|}{ Technology Use } \\
\hline Tractor use & 1 if used tractor, 0 otherwise & 0.77 & 0.42 \\
\hline Farm Implements & 1 if used any farm implements, 0 otherwise & 0.17 & 0.38 \\
\hline Chemical Fertilizer & 1 if used chemical fertilizer, 0 otherwise & 0.84 & 0.37 \\
\hline $\begin{array}{l}\text { Pesticides (herbicides or } \\
\text { insecticides) }\end{array}$ & 1 if used pesticides, 0 otherwise & 0.24 & 0.43 \\
\hline \multicolumn{4}{|l|}{ Theoretical controls } \\
\hline \multicolumn{4}{|l|}{ Human capital } \\
\hline Enrolled in school & 1 if currently enrolled, 0 otherwise & 0.17 & 0.38 \\
\hline Years of schooling & Years enrolled prior to 1996 & 5.88 & 5.82 \\
\hline Currently has wage job & 1 if now has wage job, 0 otherwise & 0.36 & 0.48 \\
\hline Currently has salaried job & 1 if now has salaried job, 0 otherwise & 0.08 & 0.27 \\
\hline Previous migration experience & Number of years outside Chitwan & 9.41 & 11.60 \\
\hline \multicolumn{4}{|l|}{ Social capital } \\
\hline Household has network tie & 1 if household has migrant, 0 otherwise & 0.58 & 0.49 \\
\hline Neighborhood prevalence & Proportion of migrants in neighborhood & 0.23 & 0.10 \\
\hline \multicolumn{4}{|l|}{ Physical capital } \\
\hline Market access & Minutes walked to nearest market (logged) & 1.97 & 1.19 \\
\hline Farmland & 1 if household owns land, 0 otherwise & 0.94 & 0.23 \\
\hline Livestock & Number of standardized units & 2.98 & 2.24 \\
\hline House plot owned & 1 if house plot owned, 0 otherwise & 0.94 & 0.24 \\
\hline Home quality index & Ranging from 4-18 & 8.99 & 3.31 \\
\hline \multicolumn{4}{|l|}{ Demographic controls } \\
\hline \multicolumn{4}{|l|}{ Gender } \\
\hline Female & 1 if female, 0 if male & 0.56 & 0.50 \\
\hline \multicolumn{4}{|l|}{ Age (Birth cohort) } \\
\hline $15-24(1972-1981)$ & 1 if yes, 0 otherwise & 0.38 & 0.48 \\
\hline $25-34(1962-1971)$ & 1 if yes, 0 otherwise & 0.23 & 0.42 \\
\hline $35-44(1952-1961)$ & 1 if yes, 0 otherwise & 0.19 & 0.39 \\
\hline $45-59(1936-1951)$ & 1 if yes, 0 otherwise & 0.20 & 0.40 \\
\hline Household size & Number of individuals in the household & 6.74 & 3.37 \\
\hline \multicolumn{4}{|l|}{ Caste/ethnicity } \\
\hline Brahmin/Chhetri & 1 if yes, 0 otherwise & 0.49 & 0.50 \\
\hline Dalit & 1 if yes, 0 otherwise & 0.10 & 0.30 \\
\hline Hill Janajati & 1 if yes, 0 otherwise & 0.14 & 0.35 \\
\hline Newar & 1 if yes, 0 otherwise & 0.06 & 0.23 \\
\hline Terai Janajati & 1 if yes, 0 otherwise & 0.21 & 0.41 \\
\hline
\end{tabular}




\section{Table 2. Multilevel Hazard Model (Odds Ratios) Estimating First Time Out-migration in} Chitwan Valley of Nepal, 1997-2001 $(\mathrm{N}=3,401)$.

\begin{tabular}{|c|c|c|c|c|c|}
\hline Measures & Model 1 & Model 2 & Model 3 & Model 4 & Model 5 \\
\hline Tractor use & $1.24(3.15)^{* *}$ & - & - & - & $1.23(3.04)^{* *}$ \\
\hline Farm Implements & - & $1.06(0.78)$ & - & - & $1.05(0.67)$ \\
\hline Chemical Fertilizer & - & - & $1.04(0.57)$ & - & $1.01(0.09)$ \\
\hline $\begin{array}{l}\text { Pesticides (herbicides or } \\
\text { insecticides) }\end{array}$ & - & - & - & $0.95(-0.49)$ & $0.95(-0.76)$ \\
\hline \multicolumn{6}{|l|}{ Theoretical controls } \\
\hline \multicolumn{6}{|l|}{ Human capital } \\
\hline Enrolled in school & $1.00(-0.03)$ & $1.02(0.21)$ & $1.00(0.07)$ & $1.00(0.06)$ & $1.00(0.01)$ \\
\hline Years of schooling & $1.04(6.13)^{* * *}$ & $1.04(5.85)^{* * *}$ & $1.04(5.97)^{* * *}$ & $1.04(6.07)^{* * *}$ & $1.04(6.02)^{* * *}$ \\
\hline Currently has wage job & $1.07(1.24)$ & $1.07(1.23)$ & $1.06(1.05)$ & $1.06(1.02)$ & $1.08(1.25)$ \\
\hline Currently has salaried job & $1.69(5.70)^{* * *}$ & $1.69(5.65)^{* * *}$ & $1.69(5.66)^{* * *}$ & $1.69(5.68)^{* * *}$ & $1.69(5.68)^{* * *}$ \\
\hline Previous migration experience & $1.01(4.10)^{* * *}$ & $1.01(4.27)^{* * *}$ & $1.01(4.17)^{* * *}$ & $1.01(4.18)^{* * *}$ & $1.01(4.10)^{* * *}$ \\
\hline \multicolumn{6}{|l|}{ Social capital } \\
\hline Household has network tie & $1.60(1.20)$ & $1.68(1.33)$ & $1.72(1.39)$ & $1.75(1.42)$ & $1.61(1.22)$ \\
\hline Neighborhood prevalence & $1.25(3.91)^{* * *}$ & $1.25(3.92)^{* * *}$ & $1.24(3.84)^{* * *}$ & $1.24(3.83)^{* * *}$ & $1.24(3.89)$ \\
\hline \multicolumn{6}{|l|}{ Physical capital } \\
\hline Market access & $1.02(0.57)$ & $1.02(0.47)$ & $1.02(0.63)$ & $1.02(0.61)$ & $1.02(0.57)$ \\
\hline Farmland & $0.96(-0.34)$ & $0.96(-0.03)$ & $0.95(-0.42)$ & $0.96(-0.35)$ & $0.96(-0.33)$ \\
\hline Livestock & $0.97(-1.79)+$ & $0.97(-2.06)^{*}$ & $0.97(-1.98)^{*}$ & $0.97(-2.00)^{*}$ & $0.97(-1.92)^{*}$ \\
\hline House plot own & $0.66(-3.98)^{* * *}$ & $0.67(-3.83)^{* * *}$ & $0.66(-3.96)^{* * *}$ & $0.66(-3.93)^{* * *}$ & $0.65(-4.08)^{* * *}$ \\
\hline Home quality & $0.98(-1.52)$ & $0.99(-1.27)$ & $0.99(-1.16)$ & $0.99(-1.04)+$ & $0.98(-1.48)$ \\
\hline \multicolumn{6}{|l|}{ Demographic controls } \\
\hline \multicolumn{6}{|l|}{ Gender } \\
\hline Female & $0.74(-5.35) * * *$ & $0.74(-5.28)^{* * *}$ & $0.74(-5.31)^{* * *}$ & $0.75(-5.23)^{* * *}$ & $0.74(-5.39) * * *$ \\
\hline \multicolumn{6}{|l|}{ Age (Birth cohort) } \\
\hline $15-24(1972-1981)$ & $3.28(11.13)^{* * *}$ & $3.38(11.39)^{* * *}$ & $3.35(11.30)^{* * *}$ & $3.33(11.25)^{* * *}$ & $3.29(11.13)^{* * *}$ \\
\hline $25-34(1962-1971)$ & $1.60(4.62)^{* * *}$ & $1.64(4.83)^{* * *}$ & $1.63(4.76)^{* * *}$ & $1.62(5.11)^{* * *}$ & $1.60(4.62)^{* * *}$ \\
\hline $35-44(1952-1961)$ & $0.93(-0.70)$ & $0.96(-0.38)$ & $0.95(-0.46)$ & $0.96(-0.45)$ & $0.93(-0.70)$ \\
\hline $45-59(1936-1951)$ & - & - & - & - & - \\
\hline Household & $1.00(0.35)$ & $1.01(0.27)$ & $1.00(0.42)$ & $1.00(0.44)$ & $1.00(0.30)$ \\
\hline \multicolumn{6}{|l|}{ Ethnicity } \\
\hline Brahmin/Chhe & - & - & - & - & - \\
\hline Dalit & $1.23(1.91)^{*}$ & $1.18(2.23)$ & $1.19(1.60)$ & $1.18(1.54)$ & $1.22(1.88)+$ \\
\hline Hill Janjati & $1.27(2.65)^{* *}$ & $1.27(3.07)^{* *}$ & $1.26(2.51)^{* *}$ & $1.26(2.53)^{* *}$ & $1.22(1.88)+$ \\
\hline Newar & $0.80(-1.73)+$ & $0.77(-1.96)^{*}$ & $0.78(-1.89)^{*}$ & $0.78(-1.92)^{*}$ & $0.79(-1.79)+$ \\
\hline Terai Janjati & $0.98(-0.21)$ & $0.95(-0.49)$ & $0.95(-0.47)$ & $0.94(-0.53)$ & $0.97(-0.28)$ \\
\hline \multicolumn{6}{|l|}{ Duration } \\
\hline Month & $0.99(-2.57)^{* *}$ & $0.98(-2.65)^{* *}$ & $0.99(-2.61)^{* * *}$ & $0.99(-2.61)^{* *}$ & $0.99(-2.59)^{* *}$ \\
\hline Month squared & $1.00(-0.02)$ & $1.00(0.04)$ & $1.00(0.00)$ & $1.00(0.99)$ & $1.00(0.00)$ \\
\hline Intercept & $0.01(-19.10)^{* * *}$ & $0.01(-18.84)^{* * *}$ & $0.01(-18.61)^{* * *}$ & $0.01(-18.94)^{* * *}$ & $0.01(-18.52)^{* * *}$ \\
\hline AIC (Null Model=18160.0)\# & 17317.0 & 17326.0 & 17326.0 & 17326.0 & 17322.0 \\
\hline BIC (Null Model $=18165.0)$ \# & 17394.0 & 17403.0 & 17403.0 & 17403.0 & 17408.0 \\
\hline$-2 \log$ LL (Null Model=18156.0) \# & 17265.0 & 17274.0 & 17274.0 & 17274.0 & 17264.0 \\
\hline
\end{tabular}

$+P<.10, * P<.05, * * P<.01, * * * P<.001$ all probabilities are one-tailed, t-values in parenthesis

\# Smaller values compared to the null model values ae considered better. 


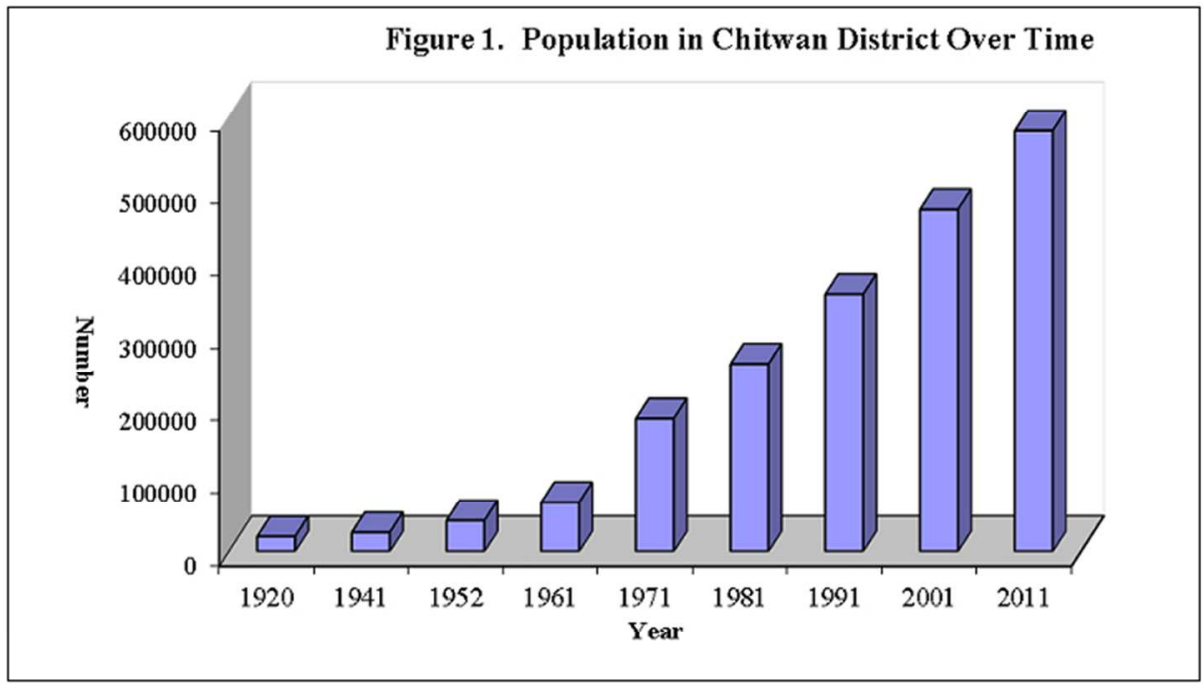

Sources:

His Majesty's Government. 1973. Mechi to Mahakali, Part 2, Midwestern Development Region. His Majesty's Government, Ministry of Communication, Kathnmandu Nepal.

Sharma, H.B. and T. R. Subedy. 1994. Nepal District Profile. National Research Associates, Kathmandu.

Central Bureau of Statistics. 1995. Population Monographs of Nepal 1995. His Majesty's Government, National Planning Commission Secretariat, Central Bureau of Statistics, Ramshaha Path, Kathmandu, Nepal.

Central Bureau of Statistics. 2001. Statistical Year Book of Nepal 2001. His Majesty's Government, National Planning Commission Secretariat, Central Bureau of Statistics Ramshaha Path, Thapathali Kathmandu, Nepal.

Central Bureau of Statistics. 2011. Statistical Year Book of Nepal 2011. His Majesty's Government, National Planning Commission Secretariat, Central Bureau of Statistics Ramshaha Path, Thapathali Kathmandu, Nepal.

Figure 1. Population in Chitwan District Over Time. $208 \times 207 \mathrm{~mm}(96 \times 96$ DPI) 


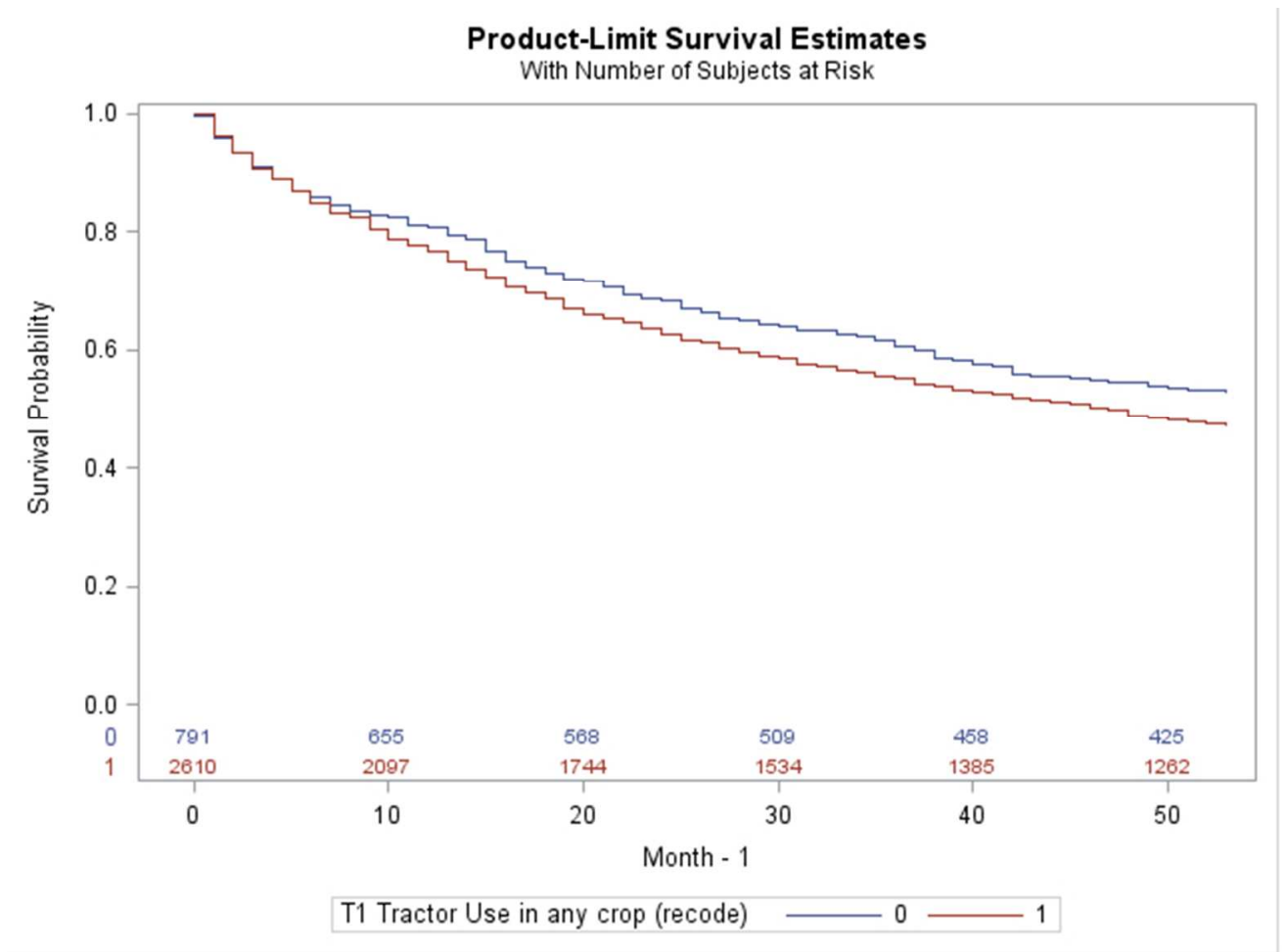

Figure 2. Kaplan-Meier Curves for Use of a Tractor and Out-migration. $170 \times 128 \mathrm{~mm}(95 \times 95 \mathrm{DPI})$ 


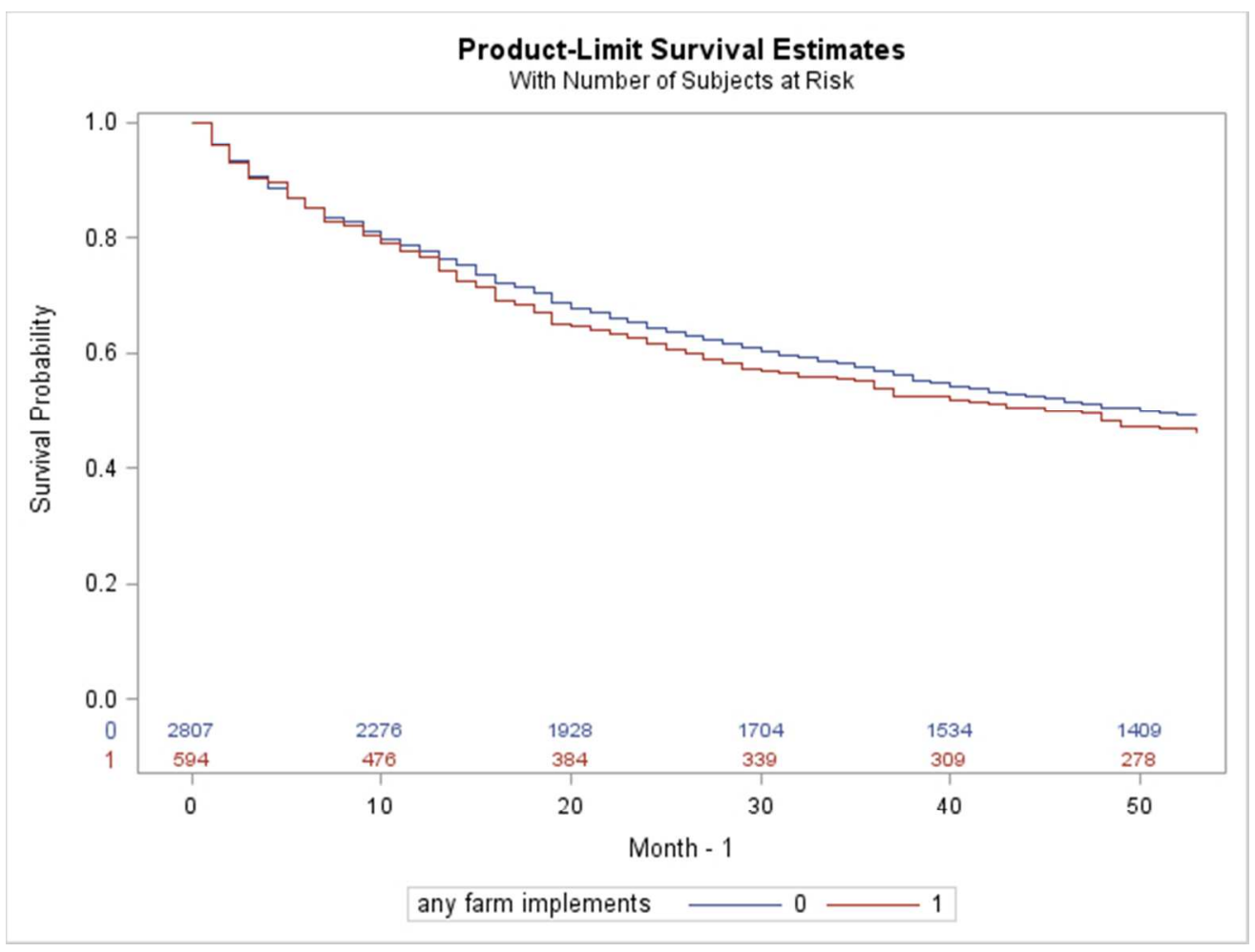

Figure 3. Kaplan-Meier Curves for Use of Farm Implements and Out-migration. $169 \times 127 \mathrm{~mm}(96 \times 96 \mathrm{DPI})$ 


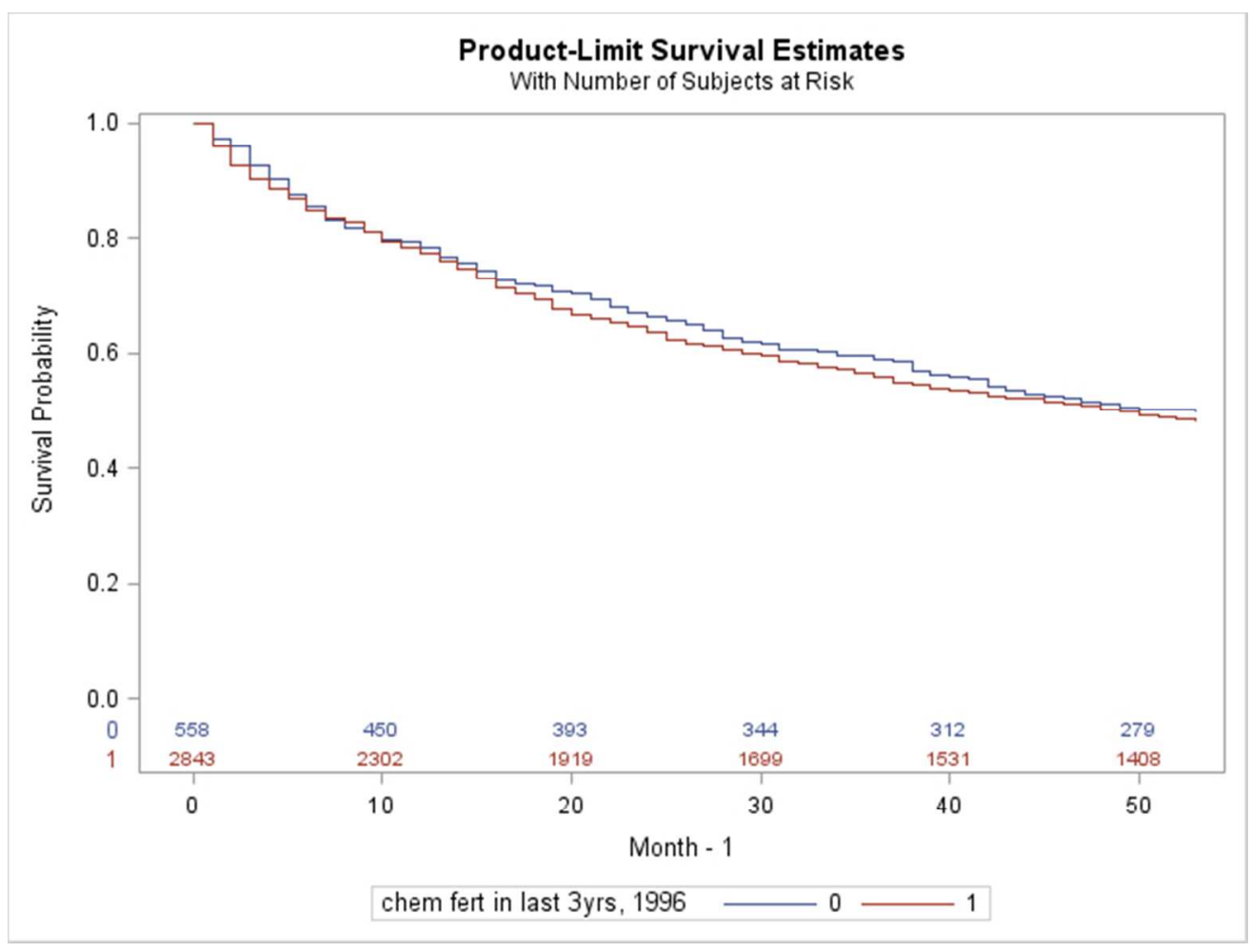

Figure 4. Kaplan-Meier Curves for Use of Chemical Fertilizers and Out-migration. $169 \times 127 \mathrm{~mm}(96 \times 96 \mathrm{DPI})$ 


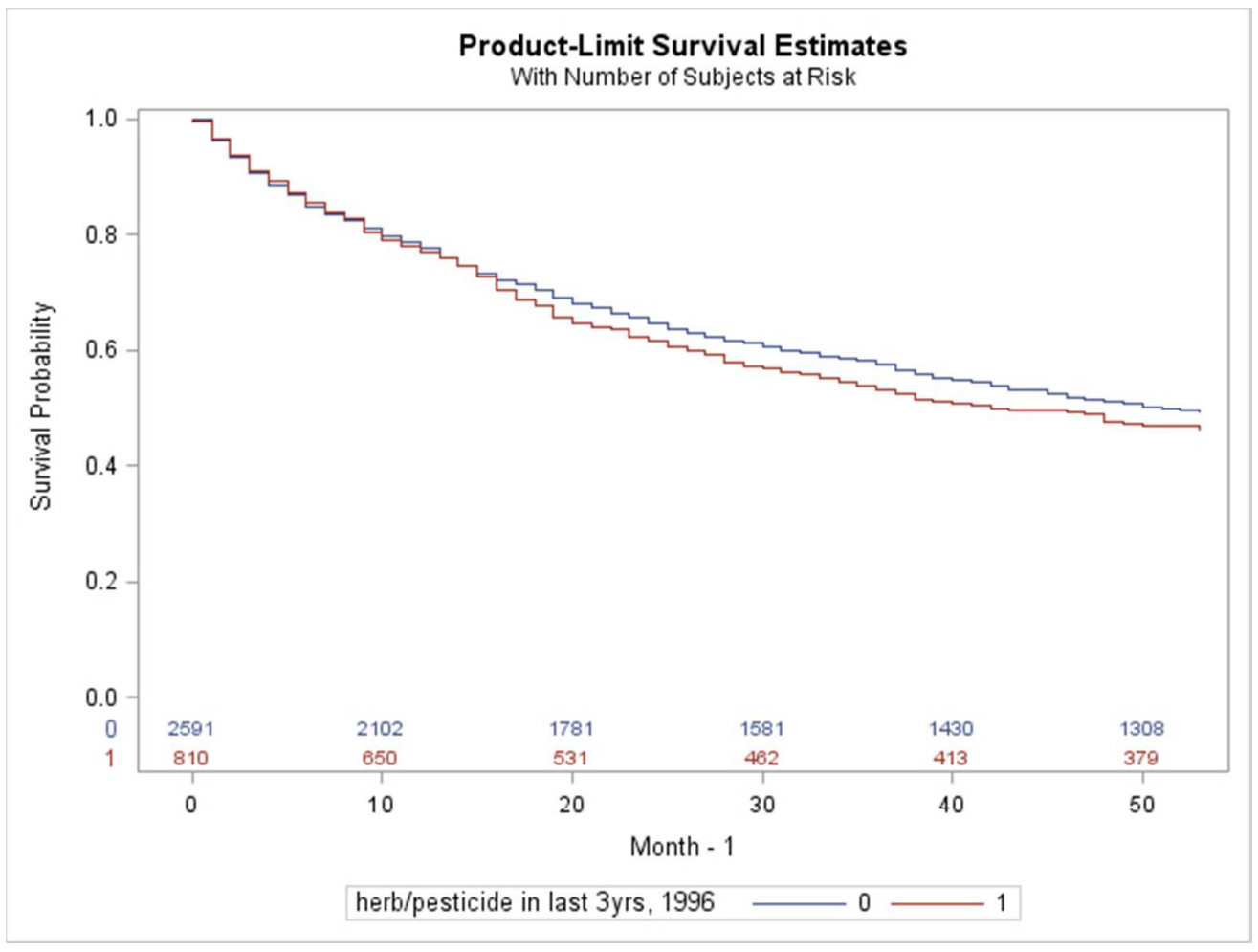

Figure 5. Kaplan-Meier Curves for Use of Pesticides and Out-migration. $169 \times 127 \mathrm{~mm}(96 \times 96 \mathrm{DPI})$ 


\section{Manuscript ID RS-15-OA-052.R1 entitled "Rural Agricultural Change and Individual Out-migration"}

Mignonette Gatchalian

\section{Revision Memo}

Rural Sociology

rseditorial@,wiley.com

Re: Manuscript ID RS-15-OA-052.R1, Rural Agricultural Change and Individual Out-migration

Dear Mignonette,

Thank you for your suggestion to "upload each figure as a separate image file (eps or tif file) of 300 dpi or high" on our manuscript, entitled "Rural Agricultural Change and Individual Outmigration." As per your suggestion, I have uploaded each figure as a separate tif file.

We greatly appreciate your suggestions. If further information is required, please contact.

Kind Regards,

Prem Bhandari

University of Michigan

\section{March 17, 2016}

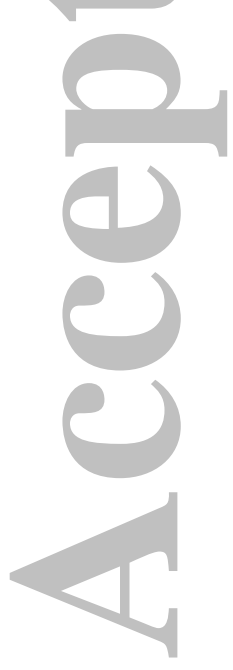

